Article

\title{
In Vitro Anti-Listerial Activities of Crude n-Hexane and Aqueous Extracts of Garcinia kola (heckel) Seeds
}

\section{Dambudzo Penduka * and Anthony I. Okoh}

Applied and Environmental Microbiology Research Group (AEMREG), Department of Biochemistry and Microbiology, University of Fort Hare, Alice, South Africa; E-Mail: aokoh@ufh.ac.za

* Author to whom correspondence should be addressed; E-Mail: 201007033@ufh.ac.za;

Tel.: +27-40-6022365; Fax: +27-086-6286824.

Received: 22 August 2011; in revised form: 19 September 2011 / Accepted: 12 October 2011 /

Published: 19 October 2011

\begin{abstract}
We assessed the anti-Listerial activities of crude n-hexane and aqueous extracts of Garcinia kola seeds against a panel of 42 Listeria isolates previously isolated from wastewater effluents in the Eastern Cape Province of South Africa and belonging to Listeria monocytogenes, Listeria grayi and Listeria ivanovii species. The $n$-hexane fraction was active against $45 \%$ of the test bacteria with zones of inhibition ranging between $8-17 \mathrm{~mm}$, while the aqueous fraction was active against $29 \%$ with zones of inhibition ranging between $8-11 \mathrm{~mm}$. The minimum inhibitory concentrations (MIC) were within the ranges of $0.079-0.625 \mathrm{mg} / \mathrm{mL}$ for the $n$-hexane extract and 10 to $>10 \mathrm{mg} / \mathrm{mL}$ for the aqueous extract. The rate of kill experiment carried out for the $n$-hexane extract only, revealed complete elimination of the initial bacterial population for L. grayi (LAL 15) at $3 \times$ and 4× MIC after 90 and $60 \mathrm{~min}$; L. monocytogenes (LAL 8) at $3 \times$ and $4 \times$ MIC after 60 and $15 \mathrm{~min}$; L. ivanovii (LEL 18) at $3 \times$ and $4 \times$ MIC after 120 and $15 \mathrm{~min}$; L. ivanovii (LEL 30) at 2, 3 and $4 \times$ MIC values after 105, 90 and 15 min exposure time respectively. The rate of kill activities were time- and concentration-dependant and the extract proved to be bactericidal as it achieved a more than $3 \log _{10}$ decrease in viable cell counts after $2 \mathrm{~h}$ exposure time for all of the four test organisms at $3 \times$ and $4 \times$ MIC values. The results therefore show the potential presence of anti-Listerial compounds in Garcinia kola seeds that can be exploited in effective anti-Listerial chemotherapy.
\end{abstract}

Keywords: Garcinia kola seeds; Listeria species; rate of kill; bactericidal 


\section{Introduction}

The genus Listeria consists of Gram-positive, non-sporeforming rod shaped bacteria which are facultatively anaerobic, catalase positive, oxidase negative and ubiquitous in nature [1]. There are six characterized Listeria species, namely Listeria monocytogenes, Listeria ivanovii, Listeria seeligeri, Listeria innocua, Listeria grayi and Listeria welshimeri [1,2]. Among these six species only two species $L$. ivanovii and L. monocytogenes are regarded as pathogenic; L. monocytogenes is pathogenic to humans and animals whilst $L$. ivanovii is pathogenic to animals mainly sheep and cattle causing the bacteremia listeriosis [2,3]. Some studies have however implicated L. seeligeri [4], L. grayi [1,5,6] and L. ivanovii in human listeriosis [7,8] and L .innocua in animal listeriosis [9] thereby also showing the potential pathogenicity of some of the Listeria species apart from L. monocytogenes and L. ivanovii.

Listeriosis is a severe food-borne disease characterized by bacteremia, meningitis and encephalitis individuals usually at high risk are those with impaired cell-mediated immunity, including neonates, pregnant woman, elderly persons, and the immune-compromised patients [10]. L. monocytogenes is an invasive, intracellular pathogen that can transverse the placenta in pregnant women and infect the fetus, although some intrauterine infection may be the result of ascending spread of the bacteria from vaginal colonization resulting in abortion, birth of a stillborn fetus or a baby with generalized infection (granulomatosis infantiseptica), and sepsis or meningitis in the neonate such that it is of particular high risk for pregnant women [11-13].

Listeriosis is regarded as a food-borne disease because most of the listeriosis cases are mainly caused by consumption of contaminated food [2,13,14], foods such as ready-to-eat meat products and milk products such as cheese $[13,15]$. In addition to its ubiquitous nature, the Listeria species presents a particular concern with respect to food handling because of the ability to grow at temperatures of $0-45{ }^{\circ} \mathrm{C}$ making the species able to grow at refrigerator temperatures commonly used to control pathogens in foods. It can also multiply at high salt concentration (10\% Sodium chloride) and at $\mathrm{pH}$ values ranging $4.5-9[2,16]$.

Standard antibiotic therapy for the effective treatment of listeriosis consists of the intravenous administration of penicillin or ampicillin often in combination with an aminoglycoside. The drug of choice in patients with a known allergy to penicillins is vancomycin/teicoplanin or trimethoprim/sulfamethoxazole [15]. Listeriosis has an average case-fatality rate of $20-30 \%$ despite adequate antibiotic treatment [15] and case fatality rates as high as $40 \%$ have been reported during outbreaks [11,17]. Epidemiological surveillances have shown the prevalence of antibiotic resistant strains of Listeria species to different antibiotics including those used for the treatment of listeriosis [12,18-20].

The challenge is therefore to develop effective strategies that may be able to help curb antibiotic resistance in such virulent bacteria species such as Listeria. Traditional medicinal plants such as Garcinia kola which is a plant of Central and West African origin have been shown to be potential sources of anti-bacterial compounds that can be effective against antibiotic resistant bacteria species. Garcinia kola is an evergreen, well branched medium-sized tree growing up to 12 metres tall and 1.5 metres wide in 12 years. It has a regular fruiting cycle and produces a characteristic orange-like pod, with edible portion contained in the pod yearly and it belongs to the family Guttiferae [21-23]. Garcinia kola seed also known as "bitter kola" because of its bitter taste has been and is still used 
traditionally to treat various medicinal ailments such as diarrhoea, hepatitis, asthma, dysmenorrhea, diabetes, anaemia, angina, liver disorders and also as an antidote against ingested poison [24,25].

Adedeji et al. [22] studies showed that the inclusion of Garcinia kola seed powder into the diet of pullet chickens lowered their mortality rate and also caused significant proliferation of the chickens' white blood cells specifically the lymphocytes [22]. Lymphocytes play an important role in cellular immunity as they form antibodies that attack antigens in the body; this further supports the traditional medicinal value of Garcinia kola seeds. There have also been studies by various authors that have also proven the antimicrobial activities of the seeds of this plant [26-30]. In studies by Han et al. [31] an antibacterial biflavonoid 3",4',4"',5,5",7,7"-heptahydroxy-3,8"-biflavanone (GB1) was isolated from the roots of Garcinia kola and the GB1 showed antibacterial activities against methicillin-resistant Staphylococcus aureus (MRSA) and vancomycin-resistant enterococci (VRE) [31].

The vast medicinal properties and therapeutic potentials of Garcinia kola seeds and the high listeriosis mortality rates in particular against a background of prevalent antibiotic resistant Listeria species, prompted this study to evaluate the anti-Listerial properties of the Garcinia kola seed. Despite the numerous studies that have been done on this plant, to the best of our knowledge there is no information in the literature on the in vitro anti-listerial activities of $n$-hexane and aqueous extracts of the Garcinia kola seed.

\section{Results and Discussion}

\subsection{Results}

The results of the anti-Listerial activities of the crude extracts are shown in Table 1 . The $n$-hexane extract had activity against 19 isolates whilst the aqueous extract had activity against 12 isolates in total with all the isolates that were susceptible to the aqueous extract also being susceptible to the $n$ hexane extract. The zones of inhibition ranged from $8-17 \mathrm{~mm}$ and $8-11 \mathrm{~mm}$ for the $n$-hexane and aqueous extracts respectively at a concentration of $10 \mathrm{mg} / \mathrm{mL}$. The highest zone of inhibition for the $n$ hexane extract was $17 \mathrm{~mm}$ obtained against L. ivanovii (LEL30) and L. ivanovii (LDB 7) whilst for the aqueous extract it was $11 \mathrm{~mm}$ obtained against L. ivanovii (LEL 1). The positive control (Ciprofloxacin) and negative control (5\% DMSO) were used for quality control purposes, with the positive control showing activity against all the isolates with inhibition zones ranging from 9-35 mm whilst, the negative control had no activity against all the isolates.

Table 2 shows the MIC and MBC results for both the extracts against the susceptible Listeria isolates. The $n$-hexane extract had MIC values ranges of $0.079-0.625 \mathrm{mg} / \mathrm{mL}$ with a mean value of $0.218 \mathrm{mg} / \mathrm{mL}$, whilst the MBC values ranges were $0.625-10 \mathrm{mg} / \mathrm{mL}$ with a mean value of 8.717 $\mathrm{mg} / \mathrm{mL}$. The aqueous extract had MIC values between 10 to $>10 \mathrm{mg} / \mathrm{mL}$ and $\mathrm{MBC}$ values above 10 $\mathrm{mg} / \mathrm{mL}$ for all the isolates. The $n$-hexane interms of its lower MIC and MBC values proved to be more active in comparison to the aqueous extract.

The results for the rate of kill assay for the $n$-hexane extract against the four representative Listeria species are shown in Figures 1(A),1(B),1(C) and 1(D) with standard deviations included in the curves for L. grayi (LAL 15), L. monocytogenes (LAL 8), L. ivanovii (LEL 30) and L. ivanovii (LEL 18) 
respectively. The rate of kill proved to be both time- and concentration-dependent for all the organisms. A complete bactericidal effect for L. grayi (LAL 15) was achieved at both $3 \times$ MIC and $4 \times$ MIC after 90 and 60 min exposure time. L. monocytogenes' (LAL 8) entire bacterial population was wiped out at both $3 \times$ MIC and $4 \times$ MIC after 60 and 15 min exposure time respectively. L. ivanovii's (LEL 30) entire bacterial population was eliminated at 2, 3 and 4× MIC values after 105, 90 and 15 min respectively and a complete bactericidal effect for L. ivanovii (LEL 18) was achieved at $3 \times$ MIC and $4 \times$ MIC values after 120 and 15 min exposure time respectively. The $n$-hexane extract proved to be bactericidal against all the Listeria species giving a more than $3 \log _{10}$ decrease in viable cell counts after $2 \mathrm{~h}$ exposure time.

Table 1. The anti-Listerial activities of Ciprofloxacin and the crude $n$-hexane and aqueous extracts of Garcinia kola seeds.

\begin{tabular}{|c|c|c|c|c|c|c|c|}
\hline ORGANISM & N-H & $\mathbf{A}$ & $\mathbf{C}$ & ORGANISM & N-H & $\mathbf{A}$ & $\mathbf{C}$ \\
\hline L. grayi (LAL 13) & 0 & 0 & $20 \pm 3.055$ & L. ivanovii (LEL 18) & $9 \pm 1$ & $8 \pm 0$ & $20 \pm 3.215$ \\
\hline L. ivanovii (LEL 17) & $8 \pm 0.577$ & 0 & $19 \pm 1.528$ & L. ivanovii (LEL 29) & 0 & 0 & $8 \pm 0.577$ \\
\hline L. ivanovii (LEL 30) & $17 \pm 0.577$ & 0 & $30 \pm 0.577$ & L. ivanovii (LEL 15) & 0 & 0 & $13 \pm 2.082$ \\
\hline L. ivanovii (LDB 11) & $9 \pm 0.577$ & 0 & $20 \pm 1$ & L. ivanovii (LDB 9) & $9 \pm 1$ & 0 & $25 \pm 2.082$ \\
\hline L. ivanovii (LEL9) & $9 \pm 0.577$ & 0 & $16 \pm 2.082$ & L. ivanovii (LDB 10) & $13 \pm 0$ & $8 \pm 0.577$ & $25 \pm 0.577$ \\
\hline L. ivanovii (LEL 1) & $16 \pm 1.155$ & $11 \pm 1$ & $17 \pm 0.577$ & L. ivanovii (LEL 2) & 0 & 0 & $28 \pm 1.528$ \\
\hline L. ivanovii (LEL 5) & 0 & 0 & $11 \pm 0.577$ & L. ivanovii (LEL 6) & 0 & 0 & $11 \pm 1.732$ \\
\hline L. ivanovii (LEL 3) & 0 & 0 & $35 \pm 3.055$ & L. ivanovii (LEL 4) & 0 & 0 & $14 \pm 1$ \\
\hline L. ivanovii (LEL 19) & 0 & 0 & $25 \pm 4.041$ & L. ivanovii (LEL 10) & 0 & 0 & $20 \pm 2.082$ \\
\hline L. ivanovii (LAL 9) & $11 \pm 0.577$ & 0 & $25 \pm 1.732$ & L. ivanovii (LAL 11) & $10 \pm 0.577$ & $8 \pm 0$ & $17 \pm 2.646$ \\
\hline L. grayi (LAL 12) & $8 \pm 0$ & 0 & $17 \pm 1.155$ & L. ivanovii (LAL 10) & $10 \pm 5.77$ & $8 \pm 0.577$ & $15 \pm 2.082$ \\
\hline L. grayi (LAL 15) & $10 \pm 2.082$ & $8 \pm 0$ & $18 \pm 2.082$ & L. ivanovii (LAL 14) & 0 & 0 & $30 \pm 2.517$ \\
\hline L. ivanovii (LDB 1) & 0 & 0 & $15 \pm 2.082$ & L. ivanovii (LDB 2) & 0 & 0 & $14 \pm 0$ \\
\hline L. ivanovii (LAL 6) & 0 & 0 & $19 \pm 1.155$ & L. ivanovii (LAL5) & 0 & 0 & $20 \pm 1.528$ \\
\hline L. ivanovii (LAL 7) & 0 & 0 & $20 \pm 1.528$ & L. monocytogenes (LAL 8) & $13 \pm 5.77$ & $10 \pm 1.155$ & $12 \pm 1$ \\
\hline L. ivanovii (LDB 7) & $17 \pm 0.577$ & $10 \pm 0.577$ & $27 \pm 0.577$ & L. ivanovii (LDB 12) & $16 \pm 1.528$ & $10 \pm 0.577$ & $25 \pm 1.528$ \\
\hline L. ivanovii (LDB 3) & $11 \pm 0$ & $8 \pm 0.577$ & $15 \pm 1$ & L. ivanovii (LDB 8) & 0 & 0 & $20 \pm 1.732$ \\
\hline L. ivanovii (LEL 7) & 0 & 0 & $9 \pm 1$ & L. ivanovii (LEL 8) & 0 & 0 & $30 \pm 1.528$ \\
\hline L. ivanovii (LEL 14) & 0 & 0 & $35 \pm 2$ & L. ivanovii (LEL 16) & $12 \pm 1$ & $8 \pm 0.577$ & $15 \pm 1.528$ \\
\hline L. grayi (LAL 3) & 0 & 0 & $13 \pm 3.055$ & L. ivanovii (LAL 4) & 0 & 0 & $20 \pm 2$ \\
\hline L. ivanovii (LAL 2) & $13 \pm 2.082$ & $8 \pm 0.577$ & $16 \pm 1$ & L. ivanovii (LAL 1) & 0 & 0 & $20 \pm 2$ \\
\hline
\end{tabular}

(number \pm number) denotes mean of three replicates zone of inhibition diameter in $\mathrm{mm} \pm$ standard deviation in mm; N-H: denotes $n$-Hexane extract; A: denotes aqueous extract; C: denotes Ciprofloxacin. 
Table 2. The Minimum Inhibitory Concentration (MIC) and Minimum Bactericidal Concentration (MBC) of crude $n$-hexane and aqueous extracts of Garcinia kola seeds against susceptible Listeria isolates.

\begin{tabular}{|c|c|c|c|c|}
\hline \multirow{3}{*}{ Organism } & \multicolumn{4}{|c|}{ Extracts } \\
\hline & \multicolumn{2}{|c|}{ n-Hexane } & \multicolumn{2}{|c|}{ Aqueous } \\
\hline & $\mathrm{MIC}(\mathrm{mg} / \mathrm{mL})$ & $\mathrm{MBC}(\mathrm{mg} / \mathrm{mL})$ & $\mathrm{MIC}(\mathrm{mg} / \mathrm{mL})$ & $\mathrm{MBC}(\mathrm{mg} / \mathrm{mL})$ \\
\hline L. ivanovii (LEL9) & 0.079 & 10 & - & - \\
\hline L. ivanovii (LEL 18) & 0.079 & 10 & 10 & $>10$ \\
\hline L. ivanovii (LAL 10) & 0.157 & 10 & 10 & $>10$ \\
\hline L. ivanovii (LEL 30) & 0.157 & 0.625 & - & - \\
\hline L. ivanovii (LEL 16) & 0.157 & 10 & 10 & $>10$ \\
\hline L. monocytogenes (LAL 8) & 0.079 & 5 & 10 & $>10$ \\
\hline L. ivanovii (LDB 12) & 0.157 & 5 & $>10$ & $>10$ \\
\hline L. ivanovii (LDB 10) & 0.079 & 10 & 10 & $>10$ \\
\hline L. ivanovii (LEL 1) & 0.157 & 10 & $>10$ & $>10$ \\
\hline L. ivanovii (LAL 11) & 0.625 & 10 & 10 & $>10$ \\
\hline L. ivanovii (LDB 3) & 0.079 & 10 & 10 & $>10$ \\
\hline L. grayi (LAL 15) & 0.079 & 10 & 10 & $>10$ \\
\hline L. grayi (LAL 12) & 0.625 & 10 & - & _- \\
\hline L. ivanovii (LDB 11) & 0.079 & 10 & - & - \\
\hline L. ivanovii (LAL 2) & 0.157 & 10 & 10 & $>10$ \\
\hline L. ivanovii (LEL 17) & 0.625 & 10 & - & - \\
\hline L. ivanovii (LDB 7) & 0.079 & 10 & 10 & $>10$ \\
\hline L. ivanovii (LDB 9) & 0.625 & 5 & - & - \\
\hline L. ivanovii (LAL 9) & 0.079 & 10 & & \\
\hline
\end{tabular}

Figure 1. (A) Profile of rate of kill of $L$. grayi (LAL 15) by crude $n$-hexane extracts of Garcinia kola seeds; (B) Profile of rate of kill of L. monocytogenes (LAL 8) by crude $n$ hexane extracts of Garcinia kola seeds; (C) Profile of rate of kill of L. ivanovii (LEL 30) by crude $n$-hexane extracts of Garcinia kola seeds; (D) Profile of rate of kill of $L$. ivanovii (LEL 18) by crude $n$-hexane extracts of Garcinia kola seeds.

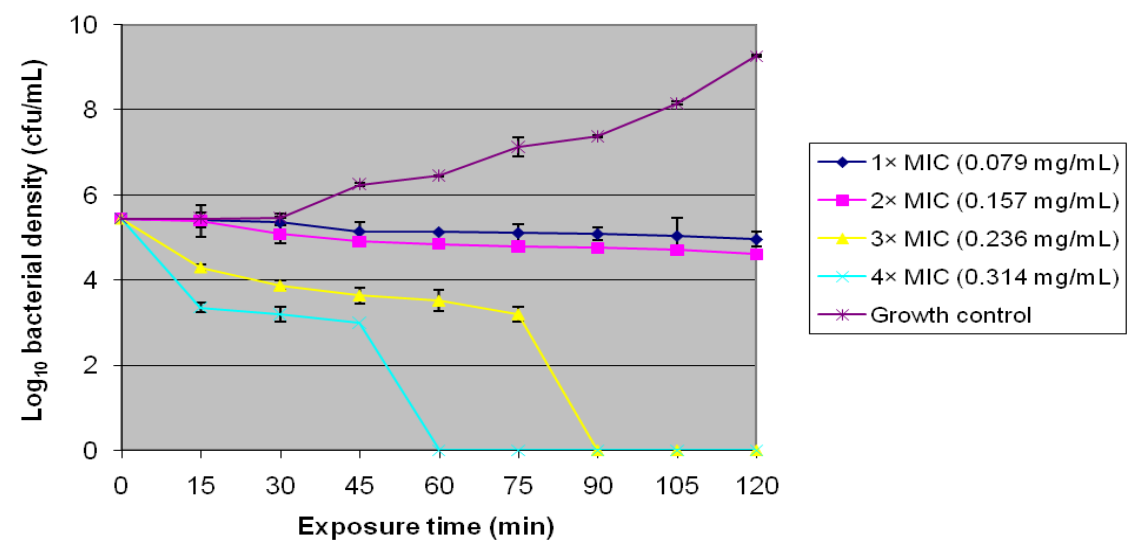


Figure 1. Cont.

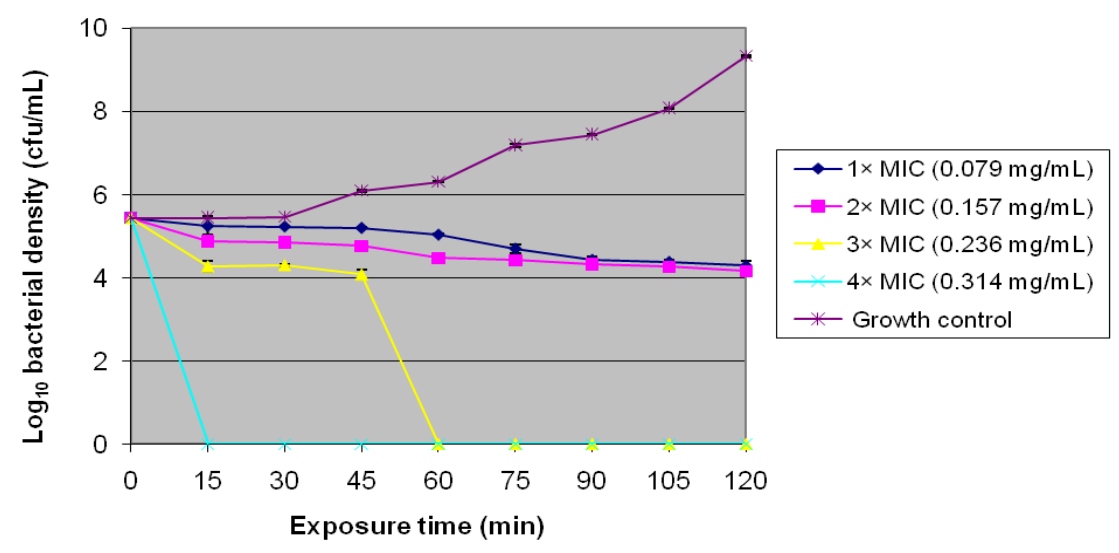

(B)

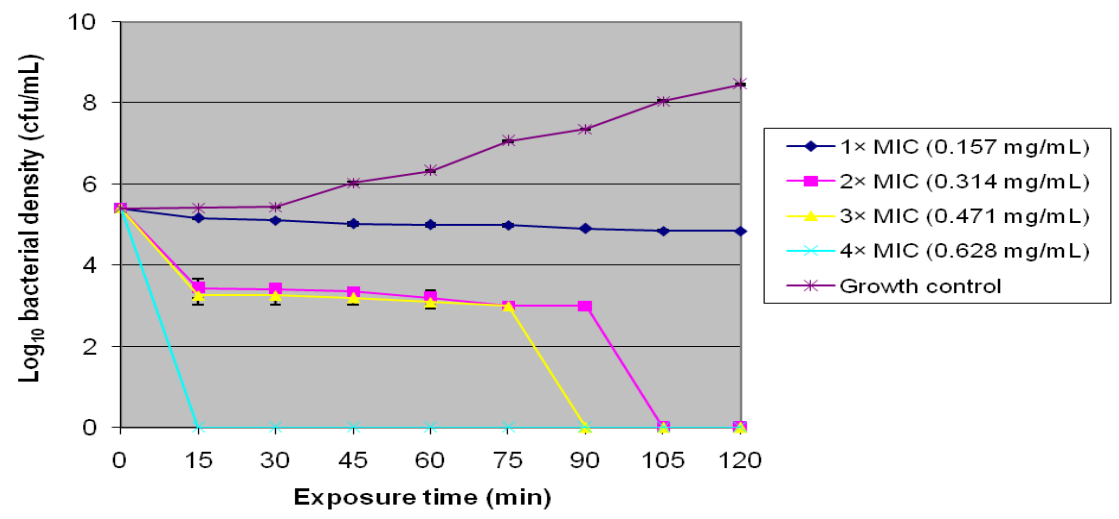

(C)

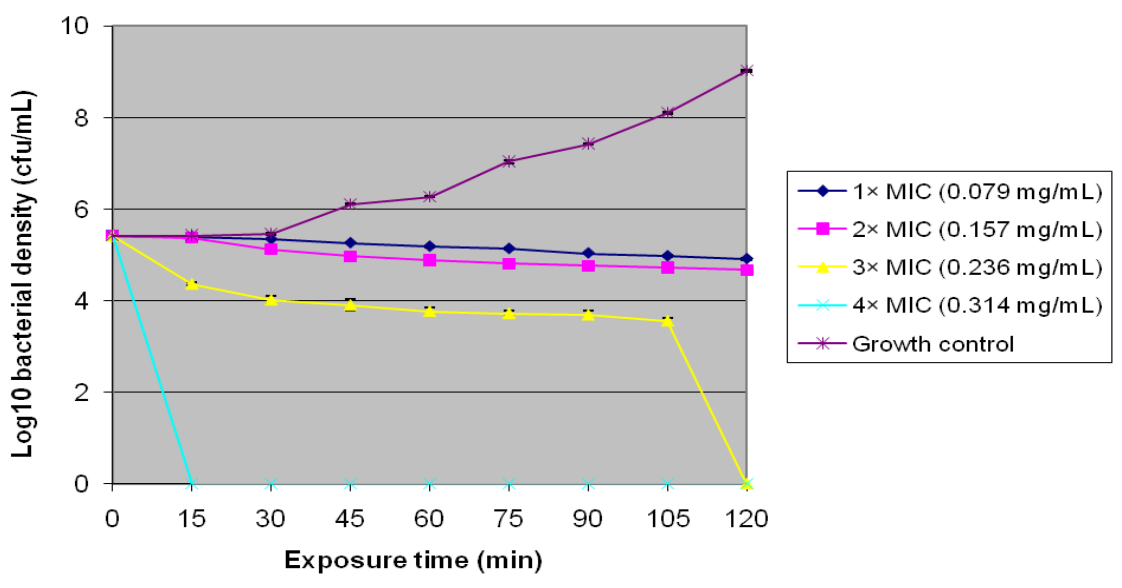

(D)

\subsection{Discussion}

The crude $n$-hexane and aqueous extracts of Garcinia kola seeds showed appreciable anti-Listerial activities from the susceptibility tests results with the $n$-hexane extract achieving a $45 \%$ activity which was higher in comparison to a $29 \%$ activity of the aqueous extract. The MIC and MBC ranges of the $n$-hexane extract were ranging between $0.079-0.625 \mathrm{mg} / \mathrm{mL}$ and $0.625-10 \mathrm{mg} / \mathrm{mL}$ respectively whilst 
the aqueous extract had higher values with MIC and $\mathrm{MBC}$ ranges of 10 to $>10 \mathrm{mg} / \mathrm{mL}$ and above $10 \mathrm{mg} / \mathrm{mL}$ respectively. These results corroborates other reports [28,32-35] that showed that the organic solvents extracts of Garcinia kola seeds are more antibacterial in comparison to the aqueous extracts, mainly because of the better solubility of the antibacterial agents in Garcinia kola such as xanthones, benzophenones, and flavonoids [31,36,37] in organic solvents than in water [29,34,38-40].

Some studies on the antibacterial activities of the crude aqueous extracts of Garcinia kola seeds have shown MIC values within the ranges of $5-20 \mathrm{mg} / \mathrm{mL}[28,29,33]$. Similarly, in our findings, 10 isolates had MIC values of $10 \mathrm{mg} / \mathrm{mL}$ whilst only two had MIC values above $10 \mathrm{mg} / \mathrm{mL}$. Variations in the methodologies used in the studies becomes the greatest obstacle in comparing results to give concrete evidence of the seeds' crude aqueous extracts MIC ranges but they however support the use of the seeds' aqueous extracts in traditional medicine to treat various medical conditions that can originate from bacterial infections such as diarrhoea, high fever and throat infections [21].

Members of the genus Garcinia from the family Guitefferae are considered as a rich and valuable source of bioactive compounds [41-44]. In a study by Pereira et al. [43], three prenylated benzophenones namely 7-epi-clusianone, garciniaphenone and guttiferone-a were obtained from silica gel chromatography of the hexane extract of powdered Garcinia brasiliensis Mart. fruits and these were found to exhibit significant activity on Leishmania (L.) amazonensis and having minimum toxicity for mammalian cells [43]. In a separate study involving non-polar solvents petroleum ether and ethyl acetate a polyisoprenyl benzophenone (kolanone) was found in the petroleum ether fraction whilst a hydroxybiflavanonols was found in the ethyl acetate fraction of Garcinia kola seeds and GB1 (a hydroxybiflavanonol) was the main component exhibiting activity against bacteria, Candida albicans and Aspergillus flavus [45]. The activity of the $n$-hexane extract in this study can therefore be attributed to a number of compounds possibly those mentioned above that can be found in Garcinia kola seeds especially those extracted through the use of non-polar solvents such as $n$-hexane.

Rate of kill assays show the bactericidal activity or the duration of a bacteriostatic effect of a fixed concentration of the antimicrobial agent, thereby providing a clear analysis of the relationship between the extent of microbial population mortality and the antimicrobial agent concentration [46,47]. The rate of kill activity of the $n$-hexane extract proved to be bactericidal at $\times 2$ (for L. ivanovii (LEL 30) only), $\times 3$ and $\times 4$ MIC values after $2 \mathrm{~h}$ exposure time for all the test organisms, since a reduction of the viable bacterial density of $\geq 99.9 \%$ or $\geq 3 \log _{10}$ in $\mathrm{cfu} / \mathrm{mL}$ is used as a standard of measurement for bactericidal efficacy [48,49]. The acetone extracts [33], methanol extracts [29], butanol and diethyl-ether fractions of the methanol extract [50] of Garcinia kola seeds were also found to exhibit bactericidal activities against both Gram positive and Gram negative bacteria, with the findings of Akinpelu et al.[50] and Sibanda and Okoh [33] showing a concentration- and time-dependent killing activity similar to this study.

This study therefore shows the nature of inhibition of the $n$-hexane extract of Garcinia kola seeds to be bactericidal at $3 \times$ and $4 \times$ MIC values against Listeria species as well as being concentrationand time-dependent. 


\section{Materials and Methods}

\subsection{Plant Material}

Garcinia kola seeds ground powder was obtained from the plant material collection of the Applied and Environmental Microbiology Research Group (AEMREG) laboratory, University of Fort Hare Alice, South Africa.

\subsection{Preparation of Extracts}

The method of Basri and Fan [51] was used to prepare the solvents extracts. The seed powder (100 grams) was steeped in $500 \mathrm{~mL}$ of the respective solvent ( $n$-hexane or water) for $48 \mathrm{~h}$ with shaking in an orbital shaker (Stuart Scientific Orbital Shaker, UK). The resultant extract was centrifuged at $3000 \mathrm{rpm}$ for $5 \mathrm{~min}$ at $4{ }^{\circ} \mathrm{C}$ (Beckman Model TJ-6RS Centrifuge, Great Britain), the supernatant was then filtered through Whatman No.1 filter paper while the residue was then used in the second extraction process with $300 \mathrm{~mL}$ of the respective solvents. After which the combined aqueous extract was freeze-dried at $-50{ }^{\circ} \mathrm{C}$ under vacuum, whereas the $n$-hexane extracts were concentrated under reduced pressure using a rotary evaporator at $50{ }^{\circ} \mathrm{C}$. The concentrated extracts were then allowed to dry to a constant weight under a stream of air in a fume cupboard at room temperature. Dimethyl sulphoxide (DMSO) at a concentration equal to $5 \%$ of the total volume which was made up with sterile distilled water was used to aid the reconstitution of the dried $n$-hexane extract when making different test concentrations whilst the water extracts were reconstituted in sterile distilled water.

\subsection{Test Listeria Strains}

The test Listeria isolates (42 in all) used in this study were obtained from the culture collection of the Applied and Environmental Microbiology Research Group (AEMREG) laboratory at the University of Fort Hare, Alice, South Africa. The bacteria were previously isolated from wastewater effluents and belonged to three specie groups which are L. ivanovii, L. grayi and L. monocytogenes [20].

\subsection{Preparation of the Inoculum}

The colony suspension method according to EUCAST [52] was used to prepare the inoculums of the test organisms. Briefly, colonies picked from $24 \mathrm{~h}$ old cultures grown on nutrient agar plates were used to make suspensions of the test organisms in saline solution $(0.85 \% \mathrm{NaCl})$ to give an optical density of approximately 0.1 at $600 \mathrm{~nm}$. The suspension was then diluted a hundred-fold before use.

\subsection{Antibacterial Susceptibility Test}

The sensitivity of each crude extract of the plant was determined using the agar well diffusion method as described by [53], with modifications. The prepared bacterial suspension (100 $\mu \mathrm{L})$ was inoculated into sterile molten Mueller-Hinton agar medium at $50{ }^{\circ} \mathrm{C}$ in a MacCarthney bottle, mixed gently and then poured into a sterile petri dish and allowed to solidify. A sterile $6 \mathrm{~mm}$ diameter cork borer was used to bore wells into the agar medium after which the wells were filled up with 
approximately $100 \mu \mathrm{L}$ of $10 \mathrm{mg} / \mathrm{mL}$ extract solution taking care to prevent spillage onto the surface of the agar medium. The plates were then allowed to stand on the laboratory bench for $1 \mathrm{~h}$ to allow proper diffusion of the extract into the medium before incubation at $37^{\circ} \mathrm{C}$ for $24 \mathrm{~h}$, and thereafter the zones of inhibition were observed and measured. Ciprofloxacin $(2 \mu \mathrm{g} / \mathrm{mL})$ was used as a positive control, and distilled water was used as the negative control while 5\% Dimethyl sulphoxide (DMSO) was also tested to determine its effect on each organism.

\subsection{Determination of the Minimum Inhibitory Concentration (MIC) and Minimum Bactericidal}

\section{Concentration (MBC)}

The broth microdilution assay method of EUCAST [52] was used to determine the MICs for the susceptible Listeria isolates in sterile disposable flat-bottomed 96-well microtiter plates. Two-fold serial dilutions using sterile distilled water were carried out from $10 \mathrm{mg} / \mathrm{mL}$ stock plant extracts to make nine test concentrations ranging from 0.039 to $10 \mathrm{mg} / \mathrm{mL}$ for each solvent extract. Double strength Mueller-Hinton broth $(100 \mu \mathrm{L})$ was introduced into all the 96 wells and $50 \mu \mathrm{L}$ of the varying concentrations of the extracts were added in decreasing order along with $50 \mu \mathrm{L}$ of the test organism suspension. Column 1 was used as the sterility wells containing $100 \mu \mathrm{L}$ of sterile distilled water in addition to the $100 \mu \mathrm{L}$ of Mueller-Hinton broth, column 2 was used as the positive control wells containing $100 \mu \mathrm{L}$ of the broth, $50 \mu \mathrm{L}$ of Ciprofloxacin and $50 \mu \mathrm{L}$ of the test organism whilst column 3 was used as the negative control wells containing $100 \mu \mathrm{L}$ of the broth, $50 \mu \mathrm{L}$ sterile distilled water and $50 \mu \mathrm{L}$ of the test organism whilst columns 4 to 12 were used as test wells containing $100 \mu \mathrm{L}$ of the broth, $50 \mu \mathrm{L}$ of the extract concentration and $50 \mu \mathrm{L}$ of the test organism. The plates were then incubated at $37{ }^{\circ} \mathrm{C}$ for $18-24 \mathrm{~h}$. Results were read visually by adding $40 \mu \mathrm{L}$ of $0.2 \mathrm{mg} / \mathrm{mL}$ of $\rho$-iodonitrotetrazolium violet (INT) dissolved in sterile distilled water into each well [54]. A pinkish coloration is indicative of microbial growth because of their ability to convert INT to red formazan [55]. The MIC was recorded as the lowest concentration of the extract that prevented the appearance of visible growth of the organism after $24 \mathrm{~h}$ of incubation [52].

Sudjana et al.'s method [56] was used to determine the minimum bactericidal concentration (MBC) from the MIC broth microdilution assays by subculturing $10 \mu \mathrm{L}$ volumes from each well that did not exhibit growth after $24 \mathrm{~h}$ of incubation and spot inoculating it onto fresh Mueller-Hinton agar plates. The plates were incubated for $48 \mathrm{~h}$ after which the numbers of viable colonies were counted. The MBC was defined as the lowest concentration killing more than or equal to $99.9 \%$ of the inoculum compared with initial viable counts [56].

\subsection{Rate of Kill Assay}

The time kill assay was done according to the method of Odenholt et al. [57] as described by Akinpelu et al. [50]. The selected test Listeria isolates namely L. ivanovii (LEL 18), L. grayi (LAL 15), L. monocytogenes (LAL 8) and L. ivanovii (LEL 30) were used for the rate of kill studies as representatives of the Listeria species used in the study. The turbidity of the $18 \mathrm{~h}$ old test Listeria was first standardized to $10^{8} \mathrm{cfu} / \mathrm{mL}$. Four different concentrations of the plant extract were made starting from the MIC to $4 \times$ MIC value for each test organism. A $0.5 \mathrm{~mL}$ volume of known cell density from each organism suspension was added to $4.5 \mathrm{~mL}$ of different concentrations of the extracts solutions, 
held at room temperature and the rate of kill determined over a period of $2 \mathrm{~h}$. Exactly $0.5 \mathrm{~mL}$ volume of each suspension was withdrawn at $15 \mathrm{~min}$ intervals and transferred to $4.5 \mathrm{~mL}$ of nutrient broth recovery medium containing $3 \%$ "Tween 80 " to neutralize the effects of the antimicrobial compound carryovers on the test organisms [50]. The suspension was then serially diluted and $0.5 \mathrm{~mL}$ was plated out for viable counts using the pour plate method. The plates were thereafter incubated at $37{ }^{\circ} \mathrm{C}$ for $48 \mathrm{~h}$. The control plates contained the test organism without the plant extracts. The emergent colonies were counted and compared with the counts of the culture control.

\subsection{Statistical Analysis}

SPSS 19.0 version for Windows program (SPSS, Inc.) at a 95\% confidence level was used to determine the one way ANOVA, means and standard deviations.

\section{Conclusions}

This study revealed the anti-Listerial activities of both the crude $n$-hexane and aqueous extracts of Garcinia kola seeds with the $n$-hexane extracts being more active and bactericidal. Further studies to determine the extracts interactions with standard antibiotics and to also isolate and characterize the active principles in the $n$-hexane extract are subjects of on-going investigation in our group. We conclude that Garcinia kola seeds hold promise as a potential source of therapeutic compounds that can be exploited in effective anti-Listerial therapy.

\section{Conflict of Interest}

The authors declare no conflict of interest.

\section{Acknowledgements}

This study has been made possible by a grant from the National Research Foundation (NRF) of South Africa.

\section{References}

1. Salimnia, H.; Patel, D.; Lephart, P.R.; Fairfax, M.R.; Chandrasekar, P.H. Listeria grayi: vancomycin-resistant, gram-positive rod causing bacteremia in a stem cell transplant recipient. Transpl. Infect. Dis. 2010, 12, 526-528.

2. Hain, T.; Steinweg, C.; Chakraborty, T. Comparative and functional genomics of Listeria spp. J. Biotechnol. 2006, 126, 37-51.

3. Vazquez-Boland, J.A.; Kuhn, M.; Berche, P.; Chakraborty, T.; Dominguez-Bernal, G.; Goebel, W.; Gonzalez-Zorn, B.; Wehland, J; Kreft, J. Listeria pathogenesis and molecular virulence determinants. Clin. Microbiol. Rev. 2001, 14, 584-640.

4. Rocourt, J.; Hof, H.; Schrettenbrunner, A.; Malinverni, R.; Bille, J. Acute purulent Listeria seeligeri meningitis in an immunocompetent adult. Schweiz. Med. Wochenschr. 1986, 116, $248-251$. 
5. Todeschini, G.; Friso, L.; Lombardi, S.; Casaril, M.; Fontana, R.; Corrocher, R. A case of Listeria murrayi/grayi bacteremia in a patient with advanced Hodgkin's disease. Eur. J. Clin. Microbiol. Infect. Dis. 1998, 17, 808-810.

6. Rapose, A.; Lick, S.D.; Ismail, N. Listeria grayi bacteremia in a heart transplant recipient. Transpl. Infect. Dis. 2008, 10, 434-436.

7. Cummin, A.J.; Fielding, A.K.; McLauchlin, J. Listeria ivanovii infection in a patient with AIDS. J. Infect. 1994, 28, 89-91.

8. Guillet, C.; Join-Lambert, O.; Monnier, A.L.; Leclercq, A.; Mechai, F.; Mamzer-Bruneel, M.; Bielecka, M.K.; Scortti, M.; Disson, O.; Berche, P.; et al. Human listeriosis caused by Listeria ivanovii. Emerg. Infect. Dis. 2010, 16, 136-138.

9. Walker, J.K.; Morgan, J.H.; McLauchlin, J.; Grant K.A.; Shallcross, J.A. Listeria innocua isolated from a case of ovine meningoencephalitis. Vet. Microbiol. 1994, 42, 245-253.

10. Schuppler, M.; Loessner, M.J. The opportunistic pathogen Listeria monocytogenes: pathogenicity and interaction with the mucosal immune system. Int. J. Inflamm. 2010, 704321, 1-12.

11. Schuchat, A.; Swaminathan, B.; Broome, C.V. Epidemiology of human listeriosis. Clin. Microbiol. Rev. 1991, 4, 169-183.

12. Davis, J.A.; Jackson, C.R. Comparative Antimicrobial Susceptibility of Listeria monocytogenes, L. innocua, and L. welshimeri. Microb. Drug Res. 2009, 15, 27-32.

13. Allerberger, F.; Wagner, M. Listeriosis: a resurgent foodborne infection. Clin. Microbiol. Infect. 2010, 16, 16-23.

14. Mead, P.S.; Slutsker, L.; Dietz, V.; McCaig, L.F.; Bresee, J.S.; Shapiro, C.; Griffin, P.M.; Tauxe, R.V. Food-related illness and death in the United States. Emerg. Infect. Dis. 1999, 5, $607-625$.

15. Swaminathan, B.; Gerner-Smidt, P. The epidemiology of human listeriosis. Microb. Infect. 2007, 9, 1236-1243.

16. Grau, F.H.; Vanderlinde, P.B. Growth of Listeria monocytogenes on vacuum packaged beef. J. Food Prot. 1990, 53, 739-741.

17. Altekruse, S.F.; Cohen, M.L.; Swerdlow, D.L. Emerging Foodborne diseases. Emerg. Infect. Dis. 1997, 3, 285-293.

18. Bertrand, S.; Huys, G.; Yde, M.; D’Haene, K.; Tardy, F.; Vrints, M.; Swings, J.; Collard, J. Detection and characterization of tet (M) in tetracycline-resistant Listeria strains from human and food-processing origins in Belgium and France. J. Med. Microbiol. 2005, 54, 1151-1156.

19. Rodas-Suarez, O.R.; Flores-Pedroche, J.F.; Betancourt-Rule, J.M.; Quinones-Ramirez, E.I.; Vazquez-Salinas, C. Occurrence and antibiotic sensitivity of Listeria monocytogenes strains isolated from Oysters, Fish, and Estuarine Water. App. Environ. Microbiol. 2006, 72, 7410-7412.

20. Odjadjare, E.E.O.; Obi, L.C.; Okoh, A.I. Municipal wastewater effluents as a source of Listerial pathogens in the aquatic milieu of the Eastern Cape Province of South Africa: A concern of public health importance. Int. J. Environ. Res. Public Health 2010, 7, 2376-2394.

21. Iwu, M.M. Handbook of African Medicinal Plants; CRC Press: Boca Raton, FL, USA, 1993; pp. 183-184. 
22. Adedeji, O.S.; Farinu, G.O.; Ameen, S.A.; Olayeni, T.B. The effects of dietary Bitter kola (Garcinia kola) inclusion on body weight haematology and survival rate of pullet chicks. J. Anim. Vet. Advan. 2006, 5, 184-187.

23. Anegbeh, P.O.; Iruka, C.; Nkirika, C. Enhancing germination of Bitter Cola (Garcinia Kola) Heckel: Prospects for agroforestry farmers in the Niger delta. Sci. Afr. 2006, 5, 1118-1931.

24. Adegoke, E.O.; Etkin, O.O.; Awosika, O.E. Biomedical evaluation of commonly used plant medicines. J. Ethno. Pharmacol. 1981, 4, 75-98.

25. Dalziel, J.M. The Useful Plants of West Tropical Africa; Crown agents for the colonies: London, UK, 1937.

26. Penduka, D.; Okoh, A.I. In-vitro antagonistic activities of crude dichloromethane extracts of Garcinia kola (Heckel) seeds against potentially pathogenic Vibrio species. J. Med. Plants. Res. 2011, 5, 2071-2077.

27. Njume, C.; Afolayan, A.J.; Clarke, A.M.; Ndip, R.N. Crude ethanolic extracts of Garcinia kola seeds Heckel (Guttiferae) prolong the lag phase of Helicobacter pylori: Inhibitory and bactericidal potential. J. Med. Food 2011, 14, 1-6.

28. Sibanda, T.; Olaniran, A.O.; Okoh, A.I. In-vitro antibacterial activities of crude extracts of Garcinia kola seeds against wound sepsis associated Staphylococcus strains. J. Med. Plants. Res. 2010, 4, 710-716.

29. Nwaokorie, F.; Coker, A.; Ogunsola, F.; Gaett-Jardim, E., Jr.; Gabriel, O.; Patricia, A.; Taiwo, A.; Adesola, U. Antimicrobial activities of Garcinia kola on oral Fusabacterium nucleatum and biofilm. Afr. J. Microbiol. Res. 2010, 4, 509-514.

30. Akoachere, J.F.T.K.; Ndip, R.N.; Chenwi, E.B.; Ndip, L.M.; Njock, T.E.; Anong, D.N. Antibacterial effect of Zingiber officinale and Garcinia kola on respiratory tract pathogens. East. Afr. Med. J. 2002, 79, 588-592.

31. Han, Q.B.; Lee, S.F.; Qiao, C.F.; He, Z.D.; Song, J.Z.; Sun, H.D.; Xu, H. Complete NMR assignments of the antibacterial Biflavonoid GB1 from Garcinia kola. Chem. Pharm. Bull. 2005, 53, 1034-1036.

32. Penduka, D.; Okoh, O.O.; Okoh, A.I. In-vitro antagonistic characteristics of crude aqueous and methanolic extracts of Garcinia kola (Heckel) seeds against some Vibrio bacteria. Molecules 2011, 16, 2754-2765.

33. Sibanda, T.; Okoh, A.I. In-vitro antibacterial regimes of crude aqueous and acetone extracts of Garcinia kola seeds. J. Biol. Sci. 2008, 8, 149-154.

34. Ogbulie, J.N.; Ogueke, C.C.; Nwanebu, F.C. Antibacterial properties of Uvaria chamae, Congronema latifolium, Garcinia kola, Vemonia amygdalina and Aframomium melegueta. Afr. J. Biotech. 2007, 6, 1549-1553.

35. Ezeifeka, G.O.; Orji, M.U.; Mbata, T.I.; Patrick, A.O. Antimicrobial activities of Cajanus cajan, Garcinia Kola and Xylopia aethiopica on pathogenic microorganisms. Biotechnology 2004, 3, 41-43.

36. Xu, H.; Lee, S.F. Activity of plant flavonoids against antibiotic-resistant bacteria. Phythother. Res. 2001, 15, 39-43. 
37. Okunji, C.; Komarnytsky, S.; Fear, G.; Poulev, A.; Ribnicky, D.M.; Awachie, P.I.; Ito, Y.; Raskin, I. Preparative isolation and identification of tyrosinase inhibitors from the seeds of Garcinia kola by high-speed counter-current chromatography. J. Chromatog. A 2007, 1151, 45-50.

38. Taiwo, O.; Xu, H.; Lee, S.F. Antibacterial activities of extracts from Nigerian chewing sticks. Phytother. Res. 1999, 13, 675-679.

39. Obi, V.I.; Onuoha, C. Extraction and Characterization methods of plants and plant products. In Biological and Agricultural Techniques; Ogbulie, J.N., Ojiako, O.A., Eds.; Websmedia: Owerri, Nigeria, 2000; pp. 271-286.

40. Ogueke, C.C.; Ogbulie, J.N.; Joku, H.O. Antimicrobial properties and preliminary phytochemical analysis of ethanolic extracts of Alstonia bonnie. Niger. J. Microbiol. 2006, 20, 896-899.

41. Monache, G.D.; Monache, F.D.; Waterman, P.G.; Crichton, E.G.; de Lima, R.A. Minor xanthones from Rheedia gardneriana. Phytochemistry 1984, 23, 1757-1759.

42. Almeida, L.S.B.; Murata, R.M.; Yatsuda, R.; dos Santos, M.H.; Nagem, T.J.; Alencar, S.M; Koo, H.; Rosalen, P.L. Antimicrobial activity of Rheedia brasiliensis and 7-epiclusianone against Streptococcus mutans. Phytomedicine 2008, 15, 886-891.

43. Pereira, I.O.; Marques, M.J.; Pavan, A.L.R.; Codonho, B.S.; Barbieri, C.L.; Beijo, L.A.; Doriguetto, A.C.; D’Martin, E.C.; dos Santos, M.H. Leishmanicidal activity of benzophenones and extracts from Garcinia brasiliensis Mart. Fruits. Phytomedicine 2010, 17, 339-345.

44. Zhou, Y.; Lee, S.; Choi, F.F.K.; Xu, G.; Liu, X.; Song, J.; Li, S.; Qiao, C.; Xu, H. Qualitative and quantitative analysis of polycyclic polyprenylated acylphloroglucinols from Garcinia species using ultra performance liquid chromatography coupled with electrospray ionization quadrupole time-of-flight tandem mass spectrometry. Analytica. Chimica. Acta 2010, 678, 96-107.

45. Madubunyi, I.I. Antimicrobial activities of the constituents of Garcinia kola Seeds. Int. J. Pharmacog. 1995, 33, 232-237.

46. Burt, S. Essential oils: their antibacterial properties and potential applications in foods. Int. J. Food Microbiol. 2004, 94, 223-253.

47. Oliveira, J.L.T.M.; Diniz, M.F.M.; Lima, E.O.; Souza, E.L.; Trajano, V.N.; Santos, B.H.C. Effectiveness of Origanum vulgare L. and Origanum majorana L. essential oils in inhibiting the growth of bacterial strains isolated from the patients with conjunctivitis. Braz. Arch. Biol. Technol. 2009, 52, 45-50.

48. CLSI (Clinical and Laboratory Standards Institute). Performance standards for antimicrobial susceptibility testing. CLSI approved standard M100-S15. Available online: http://www.clsi.org /source/orders/free/m100-s20-u.pdf. (accessed on 18 October 2011)

49. Pankey, G.A.; Sabath, L.D. Clinical relevance of bacteriostatic versus bactericidal mechanisms of action in the treatment of Gram positive bacterial infections. Clin. Inf. Dis. 2004, 38, 864-870.

50. Akinpelu, D.A.; Adegboye, M.F.; Adeloye, O.A.; Okoh, A.I. Biocidal activity of partially purified fractions from methanolic extract of Garcinia kola (Heckel) seeds on bacterial isolates. Biol. Res. 2008, 41, 277-287.

51. Basri, D.F.; Fan, S.H. The potential of aqueous and acetone extracts of galls of Queercus infectoria as antibacterial agents. Ind. J. Pharm. 2005, 37, 26-29. 
52. EUCAST (European Committee for Antimicrobial Susceptibility Testing). Determination of Minimum lnhibitory Concentration (MICs) of antimicrobial agents by broth dilution. Clin. Microbiol. Infect. 2003, 9, 1-7.

53. Irobi, O.N.; Moo-Young, M.; Anderson, W.A. Antimicrobial activity of Annato (Bixa orellana) extract. Int. J. Pharmacog. 1996, 34, 87-90.

54. Eloff, J.N. A sensitive and quick microplate method to determine the minimum inhibitory concentration of plants extracts for bacteria. Planta Med. 1998, 64, 711-713.

55. Iwalewa, E.O.; Suleiman, M.M.; Mdee, L.K.; Eloff, J.N. Antifungal and antibacterial activities of different extracts of Harungana madagascariensis stem bark. Pharma. Biol. 2009, 47, 878-885.

56. Sudjana, A.N.; D’Orazio, C.; Ryan, V.; Rasool, N.; Ng, J.; Islam, N; Riley, T.V.; Hammer, K.A. Antimicrobial activity of commercial Olea europaea (olive) leaf extract. Int. J. Antimicrob. Agents 2009, 33, 461-463.

57. Odenholt, I.; Lowdin, E.; Cars, O. Pharmacodynamics of telithromycin in-vitro against respiratory tract pathogens. Antimicrob. Agents Chemother. 2001, 45, 23-29.

(C) 2011 by the authors; licensee MDPI, Basel, Switzerland. This article is an open access article distributed under the terms and conditions of the Creative Commons Attribution license (http://creativecommons.org/licenses/by/3.0/). 